\title{
ANALISIS PENGARUH KEBERADAAN JALAN HERTASNING BARU TERHADAP PERUBAHAN PEMANFAATAN LAHAN DI KECAMATAN SOMBA OPU KABUPATEN GOWA
}

\author{
Risnawati $\mathrm{K}^{1}$ \\ ${ }^{1}$ Jurusan Perencanaan Wilayah dan Kota, Universitas Islam Negeri Makassar
}

\begin{abstract}
Abstrak
Kota Sungguminasa sebagai Ibukota Kabupaten Gowa telah ditetapkan sebagai salah satu pusat dalam sistem pengembangan kota terpadu MAMMINASATA, sehingga Kota Sungguminasa mempunyai fungsi dan peranan ganda dimana fungsi primer, adalah pusat kegiatan administrasi pemerintahan Kabupaten Gowa, sebagai pusat pengembangan Kabupaten Gowa, sebagai sub pusat pengembangan Kota Makassar bagi pengembangan kawasan pemukiman dan sebagai pusat kegiatan penelitian pertanian di wilayah Kabupaten Gowa.

Kondisi eksisting Jalan Hertasning Baru Kecamatan Somba Opu saat ini mengalami dinamika perkembangan kegiatan, khususnya kegiatan perekonomian yang semakin meningkat. Namun ketersediaan lahan yang dimiliki terbatas, sehingga lahan menjadi kebutuhan yang sangat penting. Intensitas penggunaan lahan yang mengarah pada terjadinya perubahan penggunaan fungsi lahan, semakin tinggi. Bila tidak diatur dan diarahkan, maka pemanfaatan lahan yang berdampak pada perubahan fungsi lahan akan menimbulkan berbagai masalah.

Penelitian ini bertujuan; (1) Untuk mengidentifikasi bagaimana perubahan fungsi lahan di Kecamatan Somba Opu setelah adanya Jalan Hertasning Baru, (2) Untuk mengidentifikasi perubahan fungsi lahan apa saja yang terjadi sebagai akibat adanya Jalan Hertasning Baru, (3) Untuk mengidentifikasi bagaimana keberadaan Jalan Hertasning Baru menterminasi perubahan fungsi lahan di Kecamatan Somba Opu.

Penelitian ini bersifat deskriptif. Pengumpulan data dilakukan melalui observasi, wawancara, dan dokumentasi. Data dianalisis melalui analisis kuantitatif.

Hasil penelitian menunjukkan bahwa perubahan fungsi lahan yang terjadi di Kecamatan Somba Opu setelah adanya Jalan Hertasning Baru yaitu semakin pesatnya pembangunan yang menyebabkan bertambahnya kebutuhan hidup, termasuk kebutuhan akan sumberdaya lahan. Kebutuhan lahan di Kecamatan Somba Opu semakin meningkat sejalan dengan pertumbuhan penduduk dan kegiatan sosial ekonomi yang menyertainya, Perubahan fungsi lahan yang terjadi sebagai akibat adanya Jalan Hertasning Baru yaitu perubahan fungsi lahan perkebunan menjadi lahan terbangun yaitu lahan permukiman dan perdagangan, dimana apabila perubahan pemanfaatan lahan ini tidak segera diatasi, akan mengakibatkan terjadinya kesemrautan kota yang dapat menimbulkan dampak negatif seperti meningkatnya polusi udara dan semakin berkurangnya daerah resapan yang dapat memicu terjadinya banjir.
\end{abstract}

Kata kunci : Pengaruh, Perubahan Fungsi, Dampak

\section{PENDAHULUAN}

Penataan ruang kota yang lebih baik dan teratur merupakan salah satu tujuan dari kota yang dicitacitakan oleh pengelola kota. Kenyataan ini menunjukkan banyak bagian dari kota di Indonesia berkembang tidak teratur dan tidak sesuai dengan perencanaan tata ruang kota telah tersedia. Oleh karena itu salah satu alternatif pengadaan tanah, pemerintah mengenalkan model pembangunan yang dengan istilah konsolidasi lahan perkotaan dengan tujuan dapat mengoptimalkan penggunaan lahan hubungannya dengan pemanfaatan, peningkatan kualitas lingkungan dan pencapaian efisiensi melalui penataan kembali dan pengaturan kembali lahan yang tidak teratur sehingga upaya terciptanya tata ruang yang berwawasan lingkungan.

Kota Sungguminasa sebagai Ibukota Kabupaten Gowa telah ditetapkan sebagai salah satu pusat dalam sistem pengembangan kota terpadu MAMMINASATA, sehingga Kota Sungguminasa mempunyai fungsi dan peranan ganda dimana fungsi primer, adalah pusat kegiatan administrasi pemerintahan Kabupaten Gowa, sebagai pusat pengembangan Kabupaten Gowa, sebagai sub pusat pengembangan Kota Makassar bagi pengembangan kawasan pemukiman dan sebagai pusat kegiatan penelitian pertanian di wilayah Kabupaten Gowa.

Selanjutnya fungsi sekunder meliputi pusat kegiatan administrasi pemerintahan yang lebih rendah, seperti kecamatan dan kelurahan/desa, pusat pengembangan lokal, seperti pertokoan dan lokal, pusat pelayanan pemukiman kota, pusat pengembangan kegiatan rekreasi terbuka di wilayah Kabupaten Gowa dan sebagai pusat kegiatan bagi pelayanan pendidikan dasar dan menengah, kesehatan serta fasilitas sosial lainnya.

Peningkatan kebutuhan akan lahan yang terjadi merupakan implikasi dari semakin beragamnya fungsi kegiatan di Kecamatan Somba Opu pada umumnya dan Jalan Hertasning Baru pada 
khususnya. Fungsi dan kegiatan tersebut antara lain perdagangan dan Jasa, serta berbagai kegiatan lainnya. Beragamnya fungsi kegiatan tersebut disebabkan oleh keunggulannya dalam hal ketersediaan fasilitas prasarana dan sarana serta kemudahan aksesibilitas sehingga mampu menarik berbagai kegiatan untuk beraglomerasi. Hal inilah yang menyebabkan sehingga Jalan Hertasning Baru di Kecamatan Somba Opu mempunyai daya tarik yang cukup besar bagi penduduk kecamatan lain. Akibatnya adalah terpusatnya jumlah penduduk, kegiatan ekonomi dan sosial masyarakat di sepanjang jalan ini.

Kondisi eksisting Jalan Hertasning Baru Kecamatan Somba Opu saat ini mengalami dinamika perkembangan kegiatan, khususnya kegiatan perekonomian yang semakin meningkat namun ketersediaan lahan yang dimiliki terbatas, sehingga lahan menjadi kebutuhan yang sangat penting. Intensitas penggunaan lahan yang mengarah pada terjadinya perubahan penggunaan fungsi lahan, semakin tinggi. Bila tidak diatur dan diarahkan, maka pemanfaatan lahan yang berdampak pada perubahan fungsi lahan akan menimbulkan berbagai masalah.

Jenis penggunaan lahan yang tercermin dari pola tata guna lahan yang terjadi sekarang ini merupakan hasil pilihan keputusan individual maupun kelompok atau oleh pihak organisasi pemerintahan yang dipengaruhi oleh berbagai faktor ekonomi yang menentukan keputusan penggunaan lahan tersebut. Beragamnya jenis penggunaan lahan dan tingginya jumlah penduduk yang membutuhkan lahan, dapat beresiko terhadap terjadinya ketidaksesuaian pemanfaatan lahan dengan rencana pemanfataan lahan yang telah ditetapkan oleh pemerintah.

Untuk mengantisipasi perkembangan Kecamatan Somba Opu setelah adanya Jalan Hertasning Baru ke depan, dimana terjadi perubahan pemanfaatan lahan yang sangat mencolok, maka diperlukan kajian-kajian tentang kecenderungan pemanfaatan lahan di Kecamatan Somba Opu.

Berdasarkan kenyataan diatas, maka penelitian ini dilaksanakan untuk mengetahui bagaimana perubahan fungsi lahan di Kecamatan Somba Opu setelah adanya Jalan Hertasning Baru, perubahan fungsi lahan apa saja yang terjadi sebagai akibat adanya Jalan Hertasning Baru dan bagaimana keberadaan Jalan Hertasning Baru menterminasi perubahan fungsi lahan di Kecamatan Somba Opu.

\section{ISI PENELITIAN}

\subsection{Metode Penelitian}

\section{a. Lokasi Penelitian}

Lokasi penelitian dilakukan di Kabupaten Gowa dengan ibukota Sungguminasa mempunyai luas wilayah sebesar 1.883,33 $\mathrm{km}^{2} \quad(188.333 \mathrm{Ha})$. Kabupaten Gowa terletak antara $120^{\circ} 33^{\prime}$ '19" hingga $13^{\circ} 15^{\prime} 57^{\prime}$ 'Bujur Timur dan 5 5' 64" hingga $5^{\circ} 34^{\prime}$
13" Lintang Selatan yang memiliki batasan administratif sebagai berikut

- Sebelah Utara berbatasan dengan Kota Makassar.

- Sebelah Selatan berbatasan dengan Kabupaten Takalar dan Jeneponto.

- Sebelah Timur bebatasan dengan Kabupaten Sinjai, Bulukumba dan Bantaeng.

- Sebelah Barat berbatasan dengan Kota Makassar.

\section{b. Jenis dan Sumber Data}

Untuk memperoleh hasil yang maksimal dalam studi ini dibutuhkan data dan informasi yang relevan dan lengkap. Adapun jenis data terdiri atas dua macam, yaitu :

1. Data kuantitatif, yang meliputi data luas lokasi penelitian (Kabupaten Gowa), kepadatan penduduk dan luas pemanfaatan lahan.

2. Data kualitatif, yang meliputi data batas dan ruang lingkup lokasi penelitian, jenis tanah dan geologi, topografi, hidrologi dan klimatologi.

\section{c. Metode Analisis}

Untuk menjawab rumusan masalah yang ada, maka digunakan metode analisis sebagai berikut :

1. Analisis yang digunakan adalah metode deskriktif kuantitatif yang dimaksudkan untuk mengetahui apa yang menyebabkan terjadinya perubahan pemanfaatan lahan. Selain itu, hal ini dimaksudkan semua hasil analisis yang diperoleh harus sesuai dengan maksud dan tujuan penelitian yang didasarkan pada fenomena yang diperoleh dari kenyataan riil dilapangan yang dikaitkan dengan teori-teori yang dipergunakan sebagai bahan acuan penelitian. Melalui metode deskriptif kuantitatif diharapkan dapat memberikan penjelasan serta uraian-uraian yang bersifat ilmiah selama melakukan penelitian tersebut. Sehingga pada tahap analisis dan penarikan kesimpulan pada akhir penelitian, data yang diperoleh dapat memberikan suatu cerminan kenyataan yang sungguh-sungguh terjadi dilapangan.

2. Analisis Superimpose (Overlay). Menurut Sujarto (1985 : 79), analisis ini digunakan untuk melihat perubahan yang terjadi pada pemanfaatan lahan di sepanjang jalan Hertasning Baru Kecamatan Somba Opu Kabupaten Gowa dari sebelum adanya jalan tersebut dan penggunaan lahan sesudah pembagunan di sepanjang Jalan Hertasning Baru. Prinsip dari analisis ini adalah melihat perubahan fungsi lahan. melalui dilakukan dengan overlay peta untuk menghasilkan intensitas perubahan lahan.

\subsection{Hasil}

a. Tinjauan Rencana Tata Ruang Kabupaten Gowa

1. Kebijaksanaan Spasial

Dalam rangka pengelolaan, penataan, pemanfaatan dan pengendalian ruang daerah 
Kabupaten Gowa, sebagai bagian integral dari tata ruang wilayah Provinsi Sulawesi Selatan, maka kebijakan yang ditempuh diarahkan bagi tercapainya penataan ruang yang optimal, efisien, dan efektif untuk mewujudkan prinsip dalam keterpaduan, keserasian, keterkaitan, dan keseimbangan perkembangan antar wilayah, sektor, daerah perkotaan, dan daerah perdesaan melalui :

- Pengelolaan kawasan lindung yang diarahkan untuk melindungi dan melestarikan lingkungan hidup yang ada dalam kawasan lindung serta pengelolaan kawasan budidaya sesuai arahan kebijaksanaan daerah.

- Mengarahkan pengelolaan kawasan perkotaan, perdesaan dan kawasan tertentu pada pemanfaatan ruang secara optimal, efisien dan efektif.

- Mengarahkan pengembangan kawasan permukiman, kehutanan, pertanian, pertambangan, perindustrian, pariwisata, dan kawasan lainnya sesuai pola penataan ruang kabupaten.

- Mengarahkan pembangunan yang diprioritaskan pada potensi perkembangan yang dicapai serta prospek pengembangan dan pengamanannya di masa yang akan datang.

Mengacu pada karakteristik wilayah serta potensi dan prospek pengembangan yang dimiliki, maka Kabupaten Gowa bersama dengan daerah lainnya dalam kawasan andalan Makassar dan sekitarnya juga dikembangkan industri, pangan, perdagangan, jasa keuangan dan perikanan dengan pusat pengembangan di Kota Makassar dan sekaligus berfungsi sebagai Pusat Pelayanan Nasional.

\section{Kebijaksanaan Tata Ruang Kabupaten Gowa}

Rencana pengembangan Kabupaten Gowa pada dasarnya diarahkan sedemikian rupa sehingga terwujud tingkat pelayanan yang efektif dan efisien sesuai dengan fungsi kota yang diharapkan. Dengan memahami problema, maka faktor penentu perkembangan kota, maka konsep rencana berdasarkan pertimbangan-pertimbangan sebagai berikut:

a. Untuk menjaga dan memelihara serta meningkatkan aksesibilitas antara kota dengan memanfaatkan jalur-jalur utama yang menghubungkan Kabupaten Gowa dengan kota sekitarnya.

b. Untuk meningkatkan hubungan lokal (antar bagian wilayah kota) perlu direncanakan jaringan-jaringan jalan yang menghubungkan unit lingkungan secara lingkungan secara keseluruhan dengan mengutamakan pola jalan yang efisien dengan tingkat pelayanan yang tinggi.

c. Jarak tiap fasilitas pelayanan baik pada pusat BWK maupun pusat lingkungan semakin terjangkau sesuai kebutuhan dan kemampuan masyarakat. d. Hubungan fungsional dari masing-masing aktifitas dalam kota.

e. Daya tampung tiap blok lingkungan.

Struktur Tata Ruang Kabupaten Gowa didasarkan pada fungsi masing-masing Bagian Wilayah Kota (BWK) sehingga terjadi hubungan fungsional antara BWK yang saling mempengaruhi struktur perkembangan kota dimasa yang akan datang. Fungsi masing-masing BWK didasarkan pada komponen-komponen pembentuk dari setiap BWK. Komponen yang dimaksud adalah pasar, kantor pemerintahan kabupaten / kecamatan, instansi lainnya seperti telkom, PLN, puskesmas, fasilitas umum, fasilitas pendidikan, terminal dan sebagainya. Komponen-komponen ini yang menyebabkan terjadinya hubungan fungsional dari masingmasing BWK. Keserasian hubungan antara komponen inilah yang membentuk struktur tata ruang kota.

Struktur tata ruang kota terwujud dari adanya dua jenis fungsi kota, yaitu fungsi primer/ dasar (F1) dan fungsi komplemen/sekunder (F2). Fungsi dasar terbentuk dari adanya kegiatan yang berorientasi pada sektor/aspek sosial ekonomi yang berskala atau tingkat pelayanan regional, sedangkan fungsi komplemen / sekunder terbentuk dari adanya kegiatan berorientasi pada sektor sosial ekonomi yang berskala kota / lokal.

Dalam kaitannya dengan analisis alternatif struktur tata ruang kota yang didasarkan pada unsur / elemen penunjang pembentuk struktur fungsi yang ada dapat digolongkan sebagai berikut :

a. Elemen pembentuk fungsi dasar

- Transportasi : jalan arteri primer, kolektor sekunder, terminal angkutan darat dan bandara.

- Perdagangan : pasar

- Jasa : Bank dan angkutan umum

b. Elemen pembentuk fungsi komplemen/ sekunder

- Pemerintahan: Kantor kecamatan, kantor kelurahan, epolisian, koramil

- Kesehatan: Puskesmas, Balai Pengobatan, BKIA

- Pendidikan: TK,SD, SLTP dan SMU

c. Unit Lingkungan : Perumahan/ permukiman dan jaringan jalan.

\section{Pembagian Kawasan Pengembangan Kabupaten Gowa}

Selanjutnya berdasarkan analisis struktur tata ruang, maka dikembangakan lima Satuan Kawasan Pengembangan (SKP) sebagai berikut:

a. Satuan Kawasan Pengembangan A, dengan Pusat Pengembangan Kawasan di Kota Sungguminasa yang sekarang berfungsi sebagi Ibukota Kabupaten Gowa dan sebagai Pusat Pengembangan Antar Wilayah meliputi Kecamatan Somba Opu, Bontomarannu dan Pallangga. Pada kawasan ini akan diarahkan pengembangan kegiatan sektor pertanian, 
industri, perdagangan, jasa, pertambangan dan pariwisata.

b. Satuan Kawasan Pengembangan B, dengan pusat pengembangan di Parang sebagai Pusat Pengembangan Wilayah pengaruhnya meliputi Kecamatan Parangloe. Pada kawasan ini akan diarahkan pengembangan kegiatan sektor pertanian, industri, pertambangan, pariwisata dan jasa.

c. Satuan Kawasan Pengembangan C, dengan pusat pengembangan di Limbung. Wilayah pengaruhnya meliputi wilayah Kecamatan Bajeng dan Bontonompo. Pada kawasan ini akan diarahkan pengembangan kegiatan pertanian, industri, pertambangan dan pariwisata.

d. Satuan Kawasan Pengembangan D, dengan pusat pengembangan di Malakaji. Wilayah pengaruhnya meliputi wilayah Kecamatan Tompobulu dan Bungaya. Pada kawasan ini akan diarahkan pengembangan kegiatan sektor pertanian, industri dan pertambangan.

e. Satuan Kawasan Pengembangan E, dengan pusat pengembangan di Malino. Wilayah pengaruhnya meliputi wilayah Kecamatan Tinggimoncong. Pada kawasan ini akan diarahkan pengembangan sektor pariwisata dan hortikultura.

f. Beberapa wilayah di Kabupaten Gowa, terutama ibukota kabupaten yaitu Kota Sungguminasa dalam konteks pengembangan Kota Metropolitan MAMMINASA (Minasamaupa), perlu dikembangkan sebagai kota atau wilayah alternatif yang memiliki daya tarik yang sebanding dengan Kota Makassar, yang selanjutnya pengembangan bersama dengan wilayah sekitarnya dikelola secara terpadu dan terintegrasi antara suatu wilayah dengan wilayah lainnya.

(Sumber : RTRW Kabupaten Gowa)

\subsection{Pembahasan}

\section{a. Analisis Pola Penggunaan Lahan}

Dari hasil survey yang dilakukan di lokasi penelitian menunjukkan bahwa pola penggunaan lahan yang terdapat di sepanjang Jalan Hertasning Baru pada saat ini masih didominasi oleh lahan perdagangan, ruko-ruko, pendidikan tinggi, pemerintah, perkantoran, dan permukiman sedangkan untuk lahan ruko terdapat di sepenjang koridor Jalan Hertasning Baru yang cenderung mengalami peningkatan dari tahun ke tahun. Keberadaan ruko-ruko tersebut menjadi daya tarik baru bagi masyarakat Kabupaten Gowa khususnya Kecamatan Somba Opu dan sekitarnya.

Dengan melihat kondisi pola penggunaan lahan yang ada, maka untuk harga lahan akan mengalami peningkatan seiring pesatnya perkembangan penggunaan lahan dan tingginya keinginan masyarakat dan pihak swasta. Namun keberadaan ruko perlu untuk dioptimalkan pertumbuhannya agar tidak memberikan wajah yang fisik ruang yang kaku di sepanjang Jalan Hertasning Baru.

\section{b. Analisis Perubahan Pemanfaatan Lahan}

Jenis perubahan pemanfaatan lahan di Kecamatan Somba Opu pada tahun 2004 sampai pada tahun 2009 terdiri dari lahan permukiman perdagangan umum dan jasa, industri, kebun campuran, hutan, bakau/mangrove, tambak dan lainlain. Secara kuantitas dapat dilihat pada tabel berikut:

Tabel.1

Luas Perubahan Pemanfaatan Lahan di Kecamatan Somba Opu Tahun 2004-2009

\begin{tabular}{|c|c|c|c|c|c|c|}
\hline \multirow[b]{2}{*}{ No } & \multirow[b]{2}{*}{$\begin{array}{l}\text { Pemanfaatan } \\
\text { Lahan }\end{array}$} & \multicolumn{4}{|c|}{ Luas Lahan (Ha) } & \multirow{2}{*}{$\begin{array}{l}\text { Luas } \\
\text { Peru- } \\
\text { bahan } \\
\text { (Ha) }\end{array}$} \\
\hline & & 2004 & $\%$ & 2009 & $\%$ & \\
\hline 1 & Permukiman & 5 & 17.80 & 9 & 32.04 & 4 \\
\hline 2 & Perkantoran & 2 & 7.12 & 2,12 & 7.55 & 0.12 \\
\hline 3 & Fasilitas & 3 & 10.68 & 5,25 & 18.69 & 2.25 \\
\hline 4 & Perdagangan & 1 & 3.56 & 1,02 & 3.63 & 0.02 \\
\hline 5 & Pemakaman/ & 1,02 & 3.63 & 1,33 & 4.73 & 0.31 \\
\hline 6 & kuburan & 2,34 & 8.33 & 1,45 & 5.16 & 0.89 \\
\hline 7 & Pendidikan & 2,1 & 7.48 & 1,00 & 3.56 & 1.1 \\
\hline 8 & Kesehatan & 1,12 & 3.99 & 1,15 & 4.09 & 0.03 \\
\hline 9 & Persawahan & 2 & 7.12 & 1,23 & 4.38 & -1.09 \\
\hline 10 & Lapangan & 2,1 & 7.48 & 1,01 & 3.60 & -1.09 \\
\hline 11 & olah raga & - & - & 1,0 & 3.56 & -1.0 \\
\hline 12 & Peribadatan & - & - & 1,65 & 5.87 & -1.65 \\
\hline 13 & $\begin{array}{l}\text { Kebun } \\
\text { campuran } \\
\text { Terminal } \\
\text { Industri } \\
\text { Lain-lain }\end{array}$ & 6,41 & 22.82 & 0,88 & 3.13 & -5.53 \\
\hline & & 28,09 & 100 & 28,09 & 100 & - \\
\hline
\end{tabular}

Sumber: Hasil analisis, Tahun 2011

Luas perubahan pemanfaatan lahan pada tabel diatas memperlihatkan bahwa di Kecamatan Somba Opu telah terjadi peningkatan dan penurunan pemanfaatan lahan. Adapun lahan yang mengalami peningkatan tertinggi di Kecamatan Somba Opu mulai dari tahun 2004-2009 terletak pada penggunaan lahan fasilitas perdagangan seluas 2.25 Ha. Sedangkan pemanfaatan lahan yang mengalami penurunan paling besar adalah pemanfaatan lahan lain-lain sebesar 5.53 Ha.

Hal tersebut di sebabkan dari beberapa hal diantaranya, peningkatan jumlah penduduk baik penduduk pribumi maupun penduduk yang melakukan migrasi dari wilayah hinterland Kecamatan Somba Opu pertahunnya, bertambahnya jumlah unit lahan perumahan, serta adanya beberapa perubahan fungsi bangunan baik secara vertikal, horizontal maupun kearah depan bangunan.

Berdasarkan hasil analisis yang dilakukan dengan membandingkan atau overlay peta pada pemanfaatan lahan tahun 2004 dan peta pemanfaatan lahan tahun 2009, terlihat bahwa di Kecamatan Somba Opu terjadi perubahan pemanfaatan lahan yang cukup mendasar.

Perubahan pemanfaatan lahan, yang pada pembahasan ini lebih spesifik pada perubahan fungsi 
lahan, dapat mengacu pada dua hal yang berbeda yaitu fungsi lahan sebelumnya atau Rencana Tata Ruang.

Perubahan yang mengacu pada fungsi sebelumnya adalah suatu fungsi baru atas lahan yang berbeda dengan fungsi lahan sebelumnya, sedangkan perubahan yang mengacu pada Rencana Tata Ruang adalah fungsi baru atas lahan yang tidak sesuai dengan yang di tentukan dalam Rencana Tata Ruang Wilayah yang disahkan.

\section{c. Upaya Untuk Mengoptimalkan Harga Lahan di Sepanjang Jalan Hertasning Baru Kecamatan Somba Opu Kabupaten Gowa}

Upaya pengendalian pemanfaatan lahan komersial, perguruan tinggi, lingkungan permukiman khususnya diperlukan untuk mengatasi dan mengantisipasi penyimpangan perubahan pemanfaatan lahan oleh kegiatan komersial, permukiman yang tidak sesuai rencana dikaitkan dengan potensi pemanfaatan lahan komersial di sepanjang Jalan Hertasning Baru. Tindakan yang pertu dilakukan dalam mengoptimalkan harga lahan di sepanjang Jalan Hertasning Baru antara lain:

1. Mengoptimalisasikan fungsi pusat sekunder dan pusat komersial lingkungan (aglomerasi) yang terdapat di sepanjang Jalan Hertasning Baru dengan berdasarkan pada Rencana Tata Ruang Kabupaten Gowa.

2. Selektifitas dan konsistensi dalam pemberian ijin pemanfaatan lahan, penetapan retribusi perubahan pemanfaatan lahan agar pengaturan pemanfaatan lahan bisa terwujudkan untuk menghindari komersialisasi lahan di sepanjang Jalan Hertasning Baru.

3. Mempersiapkan komponen kesesuaian rencana pada penetapan pajak bumi dan bangunan (PBB) sebagai perangkat pengendalian pemanfaatan ruang,

4. Serta membangun koordinasi dengan masyarakat dan pelaku kegiatan komersial dalam merumuskan strategi pengembangan kegiatan komersial yang lebih adaptif terhadap pemanfaatan lahan di sepanjang Jalan Hertasning Baru, dalam mengoptimalisasikan peningkatan nilai harga lahan.

5. Penerapan kapasitas angkutan menjadi bus berukuran sedang (hingga 35 penumpang) dan bus-bus berukuran besar (40 65 penumpang), dengan tetap mempadukan layanan bus AC dan non AC untuk menjamin keterjangkauan pengguna kalangan bawah dalam wilayah Trans Metropolitan Mamminasata.

d. Analisis Perubahan Fungsi Lahan di Kecamatan Somba Opu Setelah Adanya Jalan Hertasning Baru

Adanya perubahan-perubahan pergeseran fungsi lahan dan bangunan yang diwujudkan dalam bentuk perubahan fisik bangunan, yang semula hanya hanya mempunyai karakteristik rumah tinggal menjadi bangunan multifungsi, dengan bentuk perubahan bangunan, seperti pusat perbelanjaan rumah makan, kantor, jasa, bengkel. Implikasi dari hal tersebut di karenakan semakin tingginya kebutuhan akan lahan. Serta harga lahan di perkotaan semakin meningkat, yang menambah tinggginya intensitas kegiatan di Kecamatan Somba Opu umumnya dan Jalan Hertasning Baru khususnya.

Terjadinya perubahahan bentuk fisik bangunan (rumah hunian), yang dilakukan dengan bentuk renovasi secara vertikal (bertingkat), dan pembangunan kearah fisik depan bangunan, dimotifasi akan kebutuhan lahan/ruang yang semakin tingggi maupun harga lahan di perkotaan yang semakin meningkat. Dimaksudkan adanya perubahan - perubahan fungsi dari suatu permukiman penduduk yang semula hanya sebagai tempat tinggal/menetap, menjadi multifungsi dalam bentuk (gedung,ruko,rumah makan, toko, dan lainlain).

Perubahan fungsi lahan yang terjadi di Kecamatan Somba Opu setelah adanya Jalan Hertasning Baru yaitu semakin pesatnya pembangunan yang menyebabkan bertambahnya kebutuhan hidup, termasuk kebutuhan akan sumberdaya lahan. Kebutuhan lahan di Kecamatan Somba Opu semakin meningkat sejalan dengan pertumbuhan penduduk dan kegiatan sosial ekonomi yang menyertainya. Peningkatan kebutuhan lahan ini merupakan implikasi dari semakin beragamnya fungsi di kawasan perkotaan seperti pemerintahan, perdagangan dan jasa serta industri yang disebabkan oleh keunggulannya dalam hal ketersediaan fasilitas dan kemudahan aksesibilitas sehingga mampu menarik berbagai kegiatan untuk beraglomerasi.

\section{e. Analisis Perubahan Fungsi Lahan Apa Saja yang Terjadi Sebagai Akibat Adanya Jalan Hertasning Baru}

Perubahan fungsi lahan yang terjadi sebagai akibat adanya Jalan Hertasning Baru yaitu perubahan fungsi lahan dari lahan terbuka mulai disulap jadi perumahan mewah dan elit mulai dikerjakan seperti misalnya pembangunan perumahan persis didekat sungai, selain itu beberapa pengembang terkenal asal ibukota tidak tinggal diam setelah melihat pengembangan kawasan ini, bahkan Grup Ciputra juga berencana membangun perumahan termegah dengan hadirnya para pengembang perumahan tersebut, maka tidak lama lagi daerah persawahan akan berubah menjadi areal atau kawasan perumahan elit disekitarnya.

Sementara itu, kedepan pembangunan rumah tidak akan seramai tahun sebelumnya sebab krisis global kedepan masih mengintai sehingga para user lebih banyak bertahan untuk membeli rumah. 
f. Analisis Bagaimana Keberadaan Jalan Hertasning Baru Menterminasi Perubahan Fungsi Lahan di Kecamatan Somba Opu

Keberadaan Jalan Hertasning Baru menterminasi perubahan fungsi lahan di Kecamatan Somba Opu karena dengan adanya Jalan Hertasning Baru, aksesibilitas pada daerah atau kawasan tersebut semakin lancar sehingga dapat mendukung terjadinya pembangunan pada kawasan tersebut. Dalam hal persoalan pemanfaatan ruang yang dapat diidentifikasikan, antara lain adalah terjadinya perbenturan fungsi dan hirarki pusat-pusat premukiman dan keterkaitan antara pusat-pusat permukiman, dengan kawasan produksi ekonomi seperti ruko-ruko dan minimarket yang terdapat di sepanjang Jalan Hertasning Baru, dimana perkembangannya relatif cepat berkembang.

Sehingga dapat menyebabkan polarisasi pemanfaatan ruang di Kecamatan Somba Opu dan berdampak pada pemanfaatan lahan yang tidak terkendali, sehingga dapat menjadi ancaman bagi pengembangan kawasan di sepanjang Jalan Hertasning Baru kedepannya dalam hal pola pemanfaatan lahan yang ada di Kecamatan Somba Opu, dimana perkembangan kawasan perkotaan di sepanjang Jalan Hertasning Baru memiliki peranan yang penting dalam mendukung perkembangan kota dalam hal struktur dan pola ruang yang terdapat di kawasan perkotaan Gowa yaitu sebagai Pengendalian pertumbuhan kawasan perkotaan Gowa, kawasan yang dijadikan pengembangan jaringan transportasi, kawasan pembangunan permukiman dan layanan berbasis kebutuhan masyarakat Kota Gowa dan wilayah-wilayah disekitarnya.

\section{g. Analisis Hasil Quesioner Pada Pelaku Perubahan Fungsi Lahan di Sepanjang Jalan Hertasning Baru}

\section{Ekonomi}

Jalan Hertasning Baru merupakan salah satu pusat pelayanan masyarakat dengan kondisi sosial ekonomi bervariasitif, yang dipengaruhi oleh jenis pekerjaan yang ditekuninya. Dengan semakin bertambahnya jumlah penggunaan lahan fasilitas sosial ekonomi di sepanjang jalan tersebut, maka kecenderungan pola hidup masyarakat guna memenuhi kebutuhan akan hidup keluarga dan kebutuhan lainnya, mendorong adanya perubahan mata pencaharian dari petani ke pedagang yang mendorong tumbuhnya ekonomi masyarakat, yang pada akhirnya membawa pada peralihan fungsi lahan milik masyarakat yang diharapkan mampu menghasilkan nilai tambah yang lebih. Penduduk yang ada di sepanjang Jalan Hertasning Baru bukan hanya bekerja sebagai pegawai tetapi ada juga yang bekerja sebagai pedagang, sehingga kebutuhan akan lahan semakin meningkat. Hal ini juga yang menyebabkan masyarakatnya menginginkan pola hidup lebih baik, sehingga kegiatan ekonomi merupakan kegiatan utama yang mempengaruhi perubahan fungsi lahan di sepanjang Jalan Hertasning Baru dalam memanfaatkan sumber daya wilayah yang ada, guna memenuhi kebutuhan untuk mempertahankan kelangsungan dengan layak.

Selain itu, perkembangan ekonomi di sepanjang Jalan Hertasning Baru tentunya juga dapat menambah pendapatan daerah tersebut yang menyebabkan terjadinya perkembangan yang cukup pesat, yang dapat memicu terjadinya perubahan fungsi lahan.

Tabel. 2

Tingkat Pendapatan Masyarakat di Sepanjang Jalan Hertasning Baru (Kecamatan Somba Opu) Tahun 2010

\begin{tabular}{|c|c|}
\hline $\begin{array}{c}\text { Tingkat pendapatan } \\
\text { masyarakat }\end{array}$ & $\begin{array}{c}\begin{array}{c}\text { Responden } \\
\text { (f) }\end{array} \\
\end{array}$ \\
\hline$>900.000$ & 24 \\
\hline $700.000-900.000$ & 31 \\
\hline $500.000-699.000$ & 28 \\
\hline$<500.000$ & 17 \\
\hline Jumlah & 100 \\
\hline
\end{tabular}

Berdasarkan hasil quesioner diketahui bahwa tingkat pendapatan masyarakat memberi pengaruh terhadap perubahan fungsi lahan di sepanjang Jalan Hertasning Baru.

\section{Aparat Pemerintah}

Aparat pemerintah merupakan faktor yang mempengaruhi perubahan fungsi lahan di sepanjang Jalan Hertasning Baru karena pemerintah memiliki peranan dalam mendukung program pembangunan di sepanjang Jalan Hertasning Baru yang secara praktis diasumsikan bahwa pengambilan keputusan yang hanya dilakukan oleh pemimpin akan berbeda konsekuensi logisnya dengan model pengambilan keputusan yang melibatkan warga masyarakat. Selain itu, kurang tegasnya pemerintah yang berwenang untuk memberikan disinsentif terhadap pelanggaran pemanfaatan lahan yang dilakukan masyarakat dan para developer yang membangun tanpa memperhatikan fungsi lahan yang ada mengakibatkan terjadinya perubahan fungsi lahan yang cukup signifikan dengan makin tergerusnya luas lahan pertanian dan perkebunan yang beralih fungsi menjadi lahan permukiman, perdagangan, dan fasilitas umum/ sosial lainnya.

Terkait dengan asumsi diatas, peranan pemerintah di Kabupaten Gowa dengan gaya kepemimpinannya baik pemimpin formal maupun non formal sangat menentukan keberhasilan setiap kegiatan khususnya mengenai keberhasilan program pengelolaan permukiman ini terletak pada ada tidaknya pihak pemerintah yang dapat bertindak sebagai motivator, memiliki sikap terbuka, dan bersedia menerima masukan dari masyarakat. Dengan kata lain lebih proaktif mencari masukan 
dan pemecahan masalah yang dihadapi sehingga tampak arti penting keberadaannya ditengah masyarakat.

Untuk mengetahui peran pemerintah dalam pengembangan yang terjadi di sepanjang Jalan Hertasning Baru, sebagaimana pada tabel berikut :

Tabel. 3

Peran Aparat Pemerintah Menurut Responden di Sepanjang Jalan Hertasning

(Kecamatan Somba Opu)

Tahun 2010

\begin{tabular}{||l|c||}
\hline Peran aparat pemerintah & $\begin{array}{c}\text { Responden } \\
\text { (f) }\end{array}$ \\
\hline Sangat Baik & 2 \\
Baik & 33 \\
Kurang Baik & 36 \\
Tidak Baik & 29 \\
\hline \multicolumn{1}{|c|}{ Jumlah } & 100 \\
\hline
\end{tabular}

Sumber: Hasil Survey

\section{Partisipasi Masyarakat}

Meningkatnya jumlah penduduk dalam satu wilayah, baik itu dikarenakan arus urbanisasi dari pedesaan ke perkotaan, maupun disebabkan oleh adanya daya tarik ekonomi perkotaaan yang erat hubungannya dengan usaha mencari pekerjaan yang lebih sesuai dengan status pendidikan, serta pertambahan penduduk yang secara alami dalam satu keluarga yang mana mengalami peningkatan yang lumayan pesat, ditunjang karena adanya perbaikan-perbaikan besar dalam bidang pemeliharaan kesehatan. Di Kecamatan Somba Opu umumnya dan Jalan Hertasning Baru khususnya dengan semakin meningkatnya jumlah penduduk yang secara alami maupun non alami akan membutuhkan ruang maupun lahan yang mana sifat lahan itu sendiri tetap.

Meningkatnya tingkat pertumbuhan mendorong pula untuk memanfaatkan lahan sebagai wadah untuk melakukan aktivitas, termaksud tempat untuk bermukim. Meningkatnya jumlah penduduk telah membawa dampak bagi terjadinya perubahan fungsi lahan di sepanjang Jalan Hertasning Baru, dimana perkembangan jumlah penduduk mengalami peningkatan. Hal ini disebabkan adanya pertambahan migrasi yang cukup besar dan peningkatan aktivitas sosial ekonomi dan pemerintahan di sepanjang jalan tersebut.

Dengan bertambahnya jumlah penduduk maka akan bertambah pula fasiltas permukiman serta kebutuhan lahan lainnya yang menjadi kebutuhan penduduk, dampak dari perubahan lahan akan berpengaruh terhadap faktor lingkungan tersebut.

Faktor partisipasi adalah salah satu faktor yang mempengaruhi perubahan fungsi lahan, dimana dalam menyikapi aturan pemerintah ada masyarakat yang mengikuti aturan pemerintah, cenderung mau berpartisipasi mengikuti aturan yang ada. Ada yang cenderung tidak mau berpartisipasi mengikuti aturan yang ada dan ada masyarakat yang sama sekali tidak mau berpartisipasi mengikuti aturan pemerintah.

Tabel. 4

Tingkat Partisipasi Masyarakat Terhadap Aturan yang Ada di Sepanjang Jalan Hertasning Baru

(Kecamatan Somba Opu)

Tahun 2010

\begin{tabular}{||l|c||}
\hline \hline Tingkat partisipasi masyarakat & $\begin{array}{c}\text { Responden } \\
\text { (f) }\end{array}$ \\
\hline - Mengikuti aturan pemerintah & 20 \\
- Cenderung mau berpartisipasi & 33 \\
mengikuti aturan & 22 \\
- Cenderung tidak mau berpartisipasi \\
$\begin{array}{l}\text { mengikuti aturan } \\
\text { Sama sekali tidak mau mengikuti } \\
\text { aturan }\end{array}$ & 25 \\
\hline \multicolumn{1}{|c|}{ Jumlah } & 100 \\
\hline
\end{tabular}

Sumber: Hasil Survey

Berdasarkan hasil quesioner, diketahui bahwa tingkat partisipasi masyarakat memberi pengaruh terhadap perubahan fungsi lahan di sepanjang Jalan Hertasning Baru.

\section{KESIMPULAN}

Perubahan fungsi lahan yang terjadi di Kecamatan Somba Opu setelah adanya Jalan Hertasning Baru yaitu semakin pesatnya pembangunan yang menyebabkan bertambahnya kebutuhan hidup, termasuk kebutuhan akan sumberdaya lahan. Kebutuhan lahan di Kecamatan Somba Opu semakin meningkat sejalan dengan pertumbuhan penduduk dan kegiatan sosial ekonomi yang menyertainya.

Perubahan fungsi lahan yang terjadi sebagai akibat adanya Jalan Hertasning Baru yaitu perubahan fungsi lahan perkebunan menjadi lahan terbangun yaitu lahan permukiman dan perdagangan. Dimana apabila perubahan pemanfaatan lahan ini tidak segera diatasi, akan mengakibatkan terjadinya kesemrautan kota yang dapat menimbulkan dampak negatif seperti meningkatnya polusi udara dan semakin berkurangnya daerah resapan yang dapat memicu terjadinya banjir.

Keberadaan Jalan Hertasning Baru menterminasi perubahan fungsi lahan di Kecamatan Somba Opu, karena dengan adanya Jalan Hertasning Baru aksesibilitas pada daerah atau kawasan tersebut semakin lancar sehingga dapat mendukung terjadinya pembangunan pada kawasan tersebut.

Dalam hal persoalan pemanfaatan ruang yang dapat diidentifikasikan, antara lain adalah terjadinya perbenturan fungsi dan hirarki pusat-pusat permukiman dan keterkaitan antara pusat-pusat permukiman, dengan kawasan produksi ekonomi 
seperti ruko-ruko dan minimarket yang terdapat di sepanjang Jalan Hertasning Baru, dimana perkembangannya relatif cepat berkembang.

\section{DAFTAR PUSTAKA}

- Bintarto, R.S. Hadisuwarno, 1984, Interaksi DesaKota dan Permasalahannya, Galia Indonesia, Jakarta.

- BPS Kabupaten Gowa, 2007, Kabupaten Gowa Dalam Angka Tahun 2007, BPS Kabupaten Gowa.

- Jayadinata, J.T, 1999, Tata Guna Tanah Dalam Perencanaan Pedesaan, Perkotaan \& Wilayah, Penerbit ITB, Bandung.

- Koestoer, H.R, dkk, 2001, Dimensi Keruangan Kota, Penerbit Universitas Indonesia, Jakarta.

- McNeiil et al, 1998, www. Google.com. Faktor-Faktor yang Mempengaruhi Perubahan Pemanfaatan Lahan.

- Nurmandi.A, 1999, Manajemen Perkotaan, Lingkaran, Yogyakarta.

- Peraturan Pemerintah Republik Indonesia No 26 Tahun 2008, Tentang Rencana Tata Ruang Wilayah Nasional, Jakarta.

- Silalahi, 1992, Penggunaan Tanah dan Faktor-Faktor yang Mempengaruhinya di Daerah Pedesaan. Propinsi Sumatera Utara.

- Sitorus, O dan Sebayang B, 1996, Konsolidasi Tanah Perkotaan, Mitra Kebijakan Tanah Indonesia, Yogyakarta.

- Sujarto, 1985, Beberapa Pengertian Tentang Perencanaan Fisik. Bhatara Karya Aksara, Jakarta.

- Tamin, Ofyar, Z, 2000, Perencanaan dan Permodelan Transportasi, ITB, Bandung.

- Yunus, Hadi Sabari, 2002, Struktur Tata Ruang Kota, Pustaka Pelajar, Yogyakarta.

- Zulkaidi, D, 1999, Pemahaman Perubahan Pemanfaatan Kota Sebagai Dasar Kebijakan Penanagannnya, Jurnal PWK Vol. 10 No.2/Juni 1999. 